\title{
Photocatalytic Bacterial Inactivation Using Bi-doped TiO2/Kaolinite Under Visible Light Irradiation
}

\author{
Anthoni B.Aritonang ${ }^{1, *}$ Ajuk Sapar ${ }^{1,}$ Annisa Furqonita ${ }^{1,}$ \\ ${ }^{1}$ Department of Chemistry, FMIPA, University of Tanjungpura, Pontianak, Indonesia \\ ${ }^{*}$ Corresponding author. Email: anthoni.b.aritonang@ @ chemistry.untan. ac.id
}

\begin{abstract}
Bismuth-doped $\mathrm{TiO} 2$ immobilized on kaolinite $(\mathrm{Bi}-\mathrm{TiO} 2-\mathrm{K})$ were prepared via sol-gel method, then calcined at $450 \mathrm{oC}$ using kaolinite as the matrix and $\mathrm{Bi}(\mathrm{NO} 3) 3$ as the $\mathrm{Bi} 3+$ cationic source. The obtained $\mathrm{Bi}-\mathrm{TiO} 2-\mathrm{K}$ photocatalyst were characterized using X-ray diffraction (XRD), infrared absorption spectroscopy, diffuse reflectance spectroscopy, energy-dispersive X-ray spectroscopy (EDX) and scanning electron microscopy (SEM). The photocatalytic activity of the Bi-TiO2-K was investigated on the bacterial inactivation of Escherichia coli (EC) and Staphyloccus aureus (SA) in water solution under visible light irradiation. The photocatalytic activity test for inactivating EC and SA bacteria was determined at room temperature and $\mathrm{pH}$ 7. Under visible light irradiation for $180 \mathrm{~min}$, the $\mathrm{Bi}-\mathrm{TiO} 2-\mathrm{K}$ photocatalyst have higher bacterial inactivation as compared to unmodified $\mathrm{Bi}-\mathrm{TiO} 2$ photocatalyst. After 180 min irradiation time was required to achieve bacterial reduction for an average bacterial inoculum size of $9.5 \times 106 \mathrm{CFU} \mathrm{mL}-1$. Finally, Bi doped $\mathrm{TiO} 2-\mathrm{K}$ could be an efficient photocatalyst for bacterial strain inactivation.
\end{abstract}

Keywords: Bi-TiO2; photocatalytic; kaolinite; antibacterial inactivation, visible light.

\section{INTRODUCTION}

High population growth has resulted in higher demand for clean water, but its supply is increasingly limited. Microorganism pollutants for example bacteria and fungi are living in water can harm human health [1], [2]. Disinfection of microorganisms in water so far generally uses chlorination method. The chlorination method using chlorine gas to produce chloro-organic disinfection which is a side-product of the reaction of chlorine with natural organic matter. Chloro-organic disinfection is carcinogenic which can endanger human health [3]. Therefore, simple clean water treatment technology is required. Therefore, finding out an effective water treatment technology without harmful treatment by products is required. Therefore, it is necessary to find an effective water treatment technology, without harmful by-product.

The semiconductor-based such as titanium dioxide (TiO2) has been widely as photocatalyst for the inactivation of harmful pathogens and for the degradation of organic compounds in wastewater [4]-[6]. Titanium dioxide has been reported to be one of the most promising photocatalysts, because of its good photocatalytic activity, better efficiency, stability and low cost [7]. Although $\mathrm{TiO} 2$ generally shows high activity for the photocatalytic oxidation of organic pollutants, there are two drawbacks limiting its photocatalytic application: its low use of the solar spectrum because of its large band gap of $3.2 \mathrm{eV}$ (anatase fase crystalline), only a small UV fraction (4-5\%) of the solar light can be utilized and its relatively high electron-hole recombination rate [8].

In the past few years, bismuth-based oxide mixtures have been of great interest to researchers of visible lightactivated photocatalysts, such as Bi2O3, Bi2WO6, Bi2Mo3O12. Several papers have reported that the narrowing of the Bi band gap is the contribution of the $6 \mathrm{~s}$ orbital electron transition to the conduction band, so that the response to visible light is getting better in these metal oxides compound. The Bi3+ cation where is it has an ionic radius of $0.74 \AA$ almost the $\mathrm{Ti}^{4+}$ ion $0.68 \AA$ may be substituted by Bi3+ cations and can decrease the band gap of $\mathrm{TiO} 2$ and thereby extend its absorption into the visible light region [9].

The numerous methods have been reported in the literature related to the synthesis of $\mathrm{Bi}$-doped $\mathrm{TiO} 2$ nanoparticles to improve their photocatalytic activities. 
Lopez et al. have been prepared of $\mathrm{Bi} 3+$ doped $\mathrm{TiO} 2$ with a doping concentration up to $2 \mathrm{wt} \%$ by a sol-gel hydrothermal method [10]. The presence of $\mathrm{Bi} 3+$ in $\mathrm{TiO} 2$ enhances the photocatalytic degradation of phenol in aqueous solution under UV-vis illumination. Mao [11] have been fabricated $\mathrm{Bi}-\mathrm{TiO} 2$ using a solgel method. The $5 \%$ of $\mathrm{Bi}-\mathrm{TiO} 2$ powder shows superior photodegradation for rhodamine B efficiency of $95.6 \%$ under UV-vis irradiation for $60 \mathrm{~min}$ [11]. Magesan et al have been successfully synthesized $4 \% \quad \mathrm{Bi} 2 \mathrm{O} 3-\mathrm{TiO} 2$ nanocomposites via sol-gel method using CTAB as templating agent [12]. The responsively to visible light was found to mainly originate from the doping process as a result of the formation of new Bi states in the form of $\mathrm{Bi}-\mathrm{O}-\mathrm{Ti}$ bonds and the reduction in the electron-hole recombination rate [13]. A major issue with $\mathrm{TiO} 2$ in general is, its easily agglomerate over time to minimize their surface area, which reduces its photocatalytic activity. On the other hand, the $\mathrm{TiO} 2$ nanoparticles are difficult to separate for reuse from solution. The adsorption ability of the $\mathrm{TiO} 2$ is relatively small, which cause in low photocatalytic activity [14], [15]. One way to overcome this problem can be done by using an impregnation on solid material surface as matrix supporting.

The activated carbon is chosen broadly as the support to increase remarkably the photocatalytic activity of $\mathrm{TiO} 2$ because of the high adsorption capability of the carbon particles [16]. Therefore, improving the adsorption ability of the photocatalysts may be an efficient way to enhance the photocatalytic activity. Candraboss et al. have been synthesis activated charcoal (AC) supported bismuth (Bi)-doped Titanium dioxide ( $\mathrm{TiO} 2)$ nanocomposite by precipitation method [17]. The incorporation of $\mathrm{Bi} 3+$ into the $\mathrm{TiO} 2$ matrix shifts the absorbance of $\mathrm{TiO} 2$ to the visible region then the addition of high adsorption capacity activated charcoal to improve the efficiency of $\mathrm{TiO} 2$.

Clays such as kaolinite are known to have a higher surface area with interlayers available have been used as a support material. They are easily separable after activity thus making them promising support for photocatalysis as well. [14]. In previous studies, it is known that the addition of kaolinite can prevent the formation of $\mathrm{TiO} 2$ agglomerates in the solution [6]. In addition, kaolinite can inhibit photo electron-photo hole pair recombination rate which contributes to increasing its photocatalytic activity. Kaolinite capkala are natural clay minerals which are very abundant in Capkala village, Bengkayang region, including phylosilicates has an adsorption capacity of $0.65 \mathrm{mg} / \mathrm{g}$, potentially used as a supporting material catalyst. Kaolinite, whose layered structure alumina silicate $(\mathrm{A} 12 \mathrm{Si} 2 \mathrm{O} 5(\mathrm{OH}) 4)$ provides the possibility of retention of a variety of compounds to reduce the energy required for the activation of the semiconductor. The catalyst improvement via immobilization might also be due to the force field between the support and the $\mathrm{TiO} 2$ particles can inhibits the recombination of electron-hole pairs [18].

The main aim of this study was to develop a Bi-TiO2$\mathrm{K}$ to enhance its photocatalytic inactivation of EC and SA under visible light irradiation.

\section{MATERIALS AND METHOD}

\subsection{Chemicals and materials}

All the chemicals were of analytical grade and used as received. Titanium tetraisopropoxide $\{\mathrm{Ti}(\mathrm{OC} 3 \mathrm{H} 7) 4$, 98\% TTiP $\}$ and bismuth nitrate (Bi(NO3)3.5H2O, Sigma-Aldrich 96\%), were used as precursor of Ti4+ and $\mathrm{Bi} 3+$ for preparing $\mathrm{TiO} 2$ and $\mathrm{Bi}$ doped-TiO2 photocatalysts. Acetyl acetone $(\mathrm{C} 5 \mathrm{H} 8 \mathrm{O} 2,97 \%)$, acetic acid $(\mathrm{CH} 3 \mathrm{COOH}, 98 \%)$, ethanol $(\mathrm{C} 2 \mathrm{H} 5 \mathrm{OH}, 97 \%)$ were purchase from Merck, sodium chloride $(\mathrm{NaCl}$, Sail brand 96\%) and nitric acid (HNO3, Merck 96\%), natural kaolinite was obtained from capkala village Bengkayang. Deionized distilled water was used for preparing all aqueous solutions. Nutrient broth (Merck), inoculum bacterial E. coli Thermo ATCC 25922, and S.aureus ATCC 25923 and yeast extract (Himedia).

\subsection{Preparation of Pure Kaolinite}

5.0 grams of Kaolinite was dissolved in $40 \mathrm{~mL}$ of $\mathrm{HCl}$ $6 \mathrm{M}$, leave the solution overnight at room temperature $(30 \mathrm{oC})$ to form a precipitate. The precipitate was separated from the solution and washed using distilled water until free of $\mathrm{Cl}-$ anions, then dried it in an oven at $120{ }^{\circ} \mathrm{C}$ and followed calcined at $500{ }^{\circ} \mathrm{C}$ for 2 hours to produce pure kaolinite.

\subsection{Preparation of TiO2 and Bi-doped TiO2 Sol}

Preparation of $\mathrm{TiO}_{2}$ sol using $7.5 \mathrm{~mL}$ of TTIP and $26.5 \mathrm{~mL}$ of ethanol mixed with $2 \mathrm{~mL}$ of acetic acid, $2 \mathrm{~mL}$ of distilled water and $1 \mathrm{~mL}$ of acetylacetone in a reflux device. The mixture was stirred while being heated at 55 ${ }^{\circ} \mathrm{C}$ for 2 hours to form a TiO2 sol. To obtain a Bi-doped$\mathrm{TiO}_{2}$ sol, a solution of $\mathrm{Bi}(\mathrm{NO} 3) 3.5 \mathrm{H} 2 \mathrm{O}$ was added to the $\mathrm{TiO} 2$ sol while stirring for 2 hours. Synthesis of Bi-doped $\mathrm{TiO}_{2} /$ Kaolinite The $0.5 \mathrm{~g}$ of pure kaolinite was added in $10 \mathrm{~mL}$ distilled water and stirred for $15 \mathrm{~min}$ for uniform dispersion. Then, $25 \mathrm{~mL} \mathrm{Bi-doped} \mathrm{TiO} 2$ sol which contained of $\mathrm{Bi} 3+: \mathrm{TiO} 2$ ratio $(1.0 \% \mathrm{~b} / \mathrm{v})$ was stirred with the pure kaolinite dispersion for $4 \mathrm{~h}$ and followed aging for $12 \mathrm{~h}$ to form $\mathrm{Bi}$ doped-TiO2/kaolinite gel. The $\mathrm{Bi}$ doped-TiO2/kaolinite gel was rinsed with distilled water and dried at $80{ }^{\circ} \mathrm{C}$ for $4 \mathrm{~h}$ to form $\mathrm{Bi}$ doped-TiO2/kaolinite amorphous. Afterwards, the amorphous content was calcined at $450{ }^{\circ} \mathrm{C}$ for $3 \mathrm{~h}$ to form $\mathrm{Bi}$ doped-TiO2/kaolinite composite. $\mathrm{Bi} 3+$ cations doping, the $\mathrm{TiO} 2$ crystal and anchored into the kaolinite surface have occurred simultaneously during calcination 
treatment. The same procedure was carried out for TiO2/kaolinite composite as a control. Thus, the composited obtained were used for the further characterization and photocatalytic activity test.

\subsection{Characterization of TiO2 and Bi doped- TiO2/kaolinite}

The crystal phase of the photocatalyst were determined using an X-ray diffractometer (XRDShimadzu-7000) which was operated at $40 \mathrm{KV}$ and 30 $\mathrm{mA}$ with $\mathrm{Cu}-\mathrm{K} \square 1$ as radiation source of wavelength $1.54060 \AA$ in the range scanning $20-80^{\circ}(2 \theta)$. The average crystallite size of sample was calculate using Sherrer formula [19-21]: $\mathrm{D}=\mathrm{k} \square /(\square \cos \theta)$, where $\mathrm{k}=$ 0.94; $\square=1.54060 \AA$; $\square$ full width half maximum (FWHM), and $\theta$ diffracting angle. Optical properties of the $\mathrm{Bi}$ doped $\mathrm{TiO} 2 /$ kaolinite were investigated using UVVisible diffuse reflectance spectrophotometry (DRS, Shimadzu 2450) with software UV Probe (DRS-8000 Shimadzu). Scans were performed over 200-800 nm and the band gap energy was determined using the tauch formula (h $\square \mathrm{a}) 1 / \mathrm{h}=\mathrm{A}(\mathrm{h} \square-\mathrm{Eg})$. The functional groups present in the samples were recorded with a FTIR analysis (Shimadzu IR Prastige21) over a wavenumber range of $400-4000 \mathrm{~cm}^{-1}$.

\subsection{Bacterial inactivation assessment}

The bacterial inactivation activity of the $\mathrm{Bi}-\mathrm{TiO} 2-\mathrm{K}$ photocatalyst was evaluated under visible light irradiation conditions as described by Dedkova et al.[19]. Two different bacterial strains were used for the testing of antibacterial activity. The nutrient broth for the cultivation bacteria were used. Incubation of bacteria was conducted in thermostat for 24 hours at $200 \mathrm{rpm}$ and 37 ${ }^{\circ} \mathrm{C}$ in a shaking incubator. Suspension of the $\mathrm{Bi}-\mathrm{TiO} 2-\mathrm{K}$ photocatalyst in growth media was diluted to achieve concentrations of $5.0 \mathrm{mg} / \mathrm{ml}$ in the growth media which is contained of the bacterial inoculums of E. coli (Gram negative) and S.aureus (Gram positive) an initial cell concentration of $1.3 \square 108 \mathrm{CFU}$ its equal to optical density (OD) 0.29 and 4x109 CFU OD 0.2 respectively. The bacterial cells were harvested by centrifugation at $4000 \mathrm{rpm}$ for $10 \mathrm{~min}$ in phosphate-buffered solution $(\mathrm{pH}$ $=7.0$ ). The inactivation assessment was conducted under dark and visible light with $(\lambda \geq 400 \mathrm{~nm})$ irradiation using a lamp Light Emitting Diode (50 wat) which placed 15 $\mathrm{cm}$ above the reactor tube to induce photocatalytic reaction for 180 minutes. After the exposure, bacterial inactivation activity was measured by turbidimetric method by measuring optical density using UV-Vis spectrophotometer. The Optical Density (OD) was determined every $20 \mathrm{~min}$ at wavelength of $600 \mathrm{~nm}$ using a UV-Vis spectrophotometer method to monitor bacterial inactivation. The reduction in turbidity was evaluated as an indication of the reduced quantity of E. coli and S. aureus bacterial in solution medium.

\section{RESULTS AND DISCUSSIONS}

The XRD patterns of the $\mathrm{TiO} 2$ and $\mathrm{Bi}-\mathrm{TiO} 2$ composites after calcined at 400; 500 and 600 oC for 2 hours are shown in Fig.1

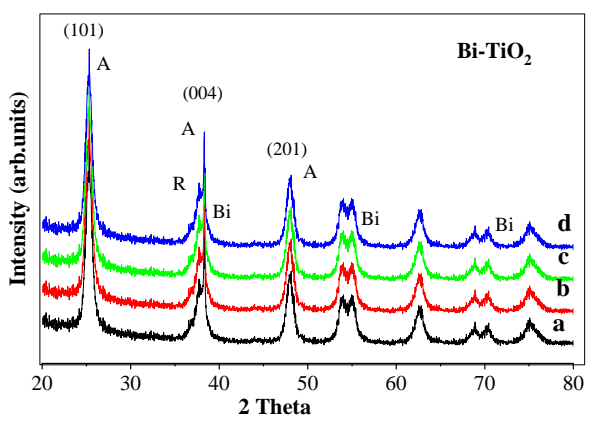

Figure 1 XRD pattern of the: a) $\mathrm{TiO}_{2}$ and $\mathrm{Bi}-\mathrm{TiO}_{2}$ after calcined: b) 400 ; c) 500 and d) $600^{\circ} \mathrm{C}$..

The diffraction peaks belonging to anatase are observable of the diffraction pattern after calcination at $400-500 \mathrm{oC}$, which are indicated the fact that $\mathrm{TiO} 2$ is present in the form of a pure crystalline phase. In the $600 \mathrm{oC}$ calcination treatment, the anatase phase was transformed into a rutile crystal phase [20]. Similar result was obtained with Xin et al. [21] where is anatase phase of $85 \%$ of the $\mathrm{Bi}-\mathrm{TiO} 2$ samples after calcined at $600{ }^{\circ} \mathrm{C}$. It is suggested that at least for calcined bellow $500^{\circ} \mathrm{C}$ the doping of $\mathrm{Bi} 3+$ cation into the $\mathrm{TiO} 2$ lattice therefore does not give significant changes in the XRD pattern.

The FTIR spectra provided functional groups information about the prepared samples. Fig 2 shows a broad spectrum of $\mathrm{Bi}-\mathrm{TiO} 2-\mathrm{K}$ which is ascribe characteristic of kaolinite [19]. The presence of broad band at $3500 \mathrm{~cm}-1$ is ascribe to the vibrations of the $\mathrm{O}-\mathrm{H}$ groups. The appearance of band at $450-550 \mathrm{~cm}-1$ represents the vibrational of Ti-O-Ti [6].

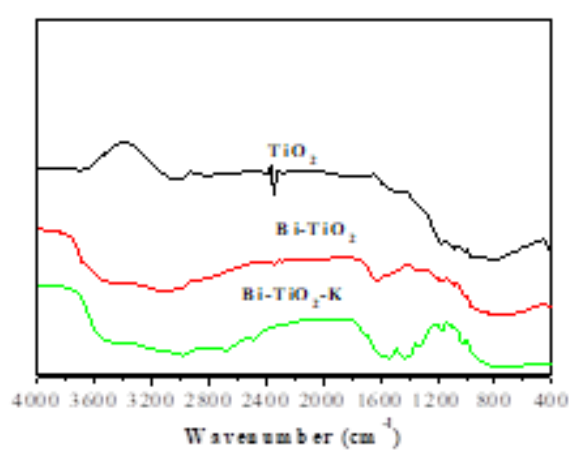

Figure 2 FTIR spectra of the: $\mathrm{TiO} 2, \mathrm{Bi}-\mathrm{TiO} 2$ and $\mathrm{Bi}-$ TiO2-K samples 
The presence of broad band at $3500 \mathrm{~cm}-1$ is ascribe to the vibrations of the $\mathrm{O}-\mathrm{H}$ groups. The appearance of band at $450-550 \mathrm{~cm}-1$ represents the vibrational of Ti-O$\mathrm{Ti}$ [6]. Regarding the $\mathrm{Bi}-\mathrm{TiO} 2$ and $\mathrm{Bi}-\mathrm{TiO} 2-\mathrm{K}$ spectrum observed in the region of $800-850 \mathrm{~cm}-1$ this is attributable to stretching of the $\mathrm{Bi}-\mathrm{O}$ [22]. This indicates that the $\mathrm{Bi} 3+$ cation was successfully incorporating in $\mathrm{TiO} 2$ lattice sites. In addition is less information about $\mathrm{Bi}-\mathrm{TiO} 2$ due to its very broad bands of $\mathrm{Bi}-\mathrm{TiO} 2-\mathrm{K}$.
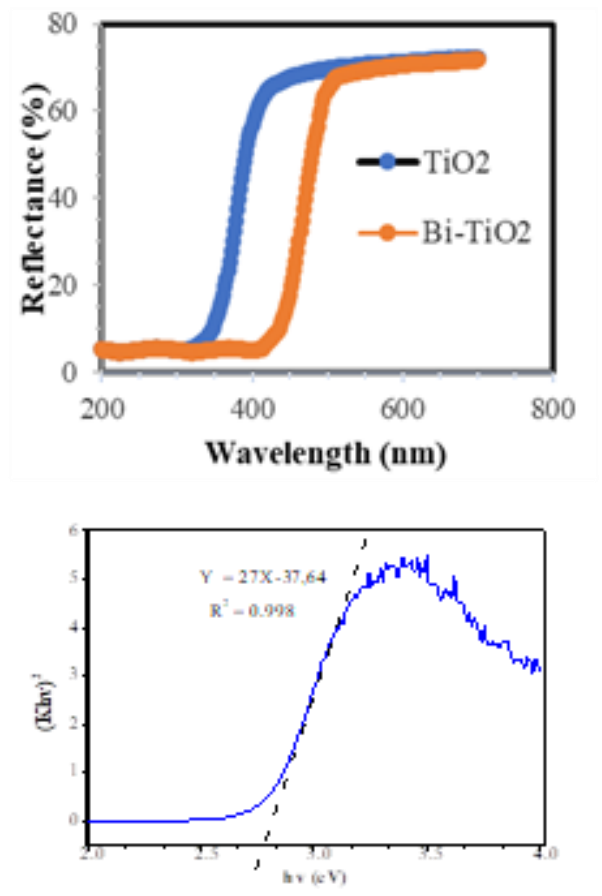

Figure 3 UV-vis DRS of a) pure $\mathrm{TiO}_{2}$ and $\mathrm{Bi}^{-} \mathrm{TiO}_{2}$; b) Tauch plot $(\mathrm{Khv})^{2}$ vs hv of $\mathrm{Bi}^{-\mathrm{TiO}_{2}}$

The reflectance $(\% \mathrm{R})$ properties of the prepared samples were examined using the UV-vis DRS method. Fig. 3 shows the corresponding UV-vis DRS of pure $\mathrm{TiO} 2$, and $\mathrm{Bi}-\mathrm{TiO} 2$. The absorption edge of pure $\mathrm{TiO} 2$ is below $400 \mathrm{~nm}$ due to the intrinsic inter-band transition absorption of anatase $\mathrm{TiO} 2$. Compared with pure $\mathrm{TiO} 2$, the respective optical absorptions of $\mathrm{Bi}-\mathrm{TiO} 2$ were enhanced to the visible light region. It indicates that the lattice defects and disorders introduced through the incorporation of the $\mathrm{Bi} 3+$ cations into $\mathrm{TiO} 2$ lattice sites [20]. The band gap energy ( $\mathrm{Eg})$ of the photocatalysts was determined using Tauc equation [6], [23], [24].

$(\alpha h v)=A(h v-E g)^{2}$

where $\mathrm{k}$ is the absorption coefficient, $\mathrm{A}$ is a constant depending on electronic transitions and $\mathrm{h} \square$ is the photon energy. The band gap energy (Eg) was obtained by taking the intercept of the extrapolation of the linear region of the plot (kh $\square) 2$ versus $\mathrm{h} \square$ (Fig. 3b). The band gap of the Bi- TiO2 $(2.76 \mathrm{eV})$ decrease from $3.22 \mathrm{eV}$ (TiO2) is caused by incorporating $\mathrm{Bi} 3+$ cation to form $\mathrm{Bi}-\mathrm{O}-\mathrm{Ti}$ bonds [10]. These results suggest that $\mathrm{Bi}-\mathrm{TiO} 2$ photocatalyst exhibit enhancement in photoresponse under visible light. This red shift which occurred for Bi$\mathrm{TiO} 2$ was evidenced by its corresponding into consideration the spin exchange interaction sp-d between band electrons and localized d electrons of Ti4+ cations substituting by the $\mathrm{Bi3}+$ ions [17], [25]. In addition, after $\mathrm{Bi}$ doping onto $\mathrm{TiO} 2$ lattice sites, the obtained photocatalysts showed a significantly enhanced optical absorption extending to the visible-light region.
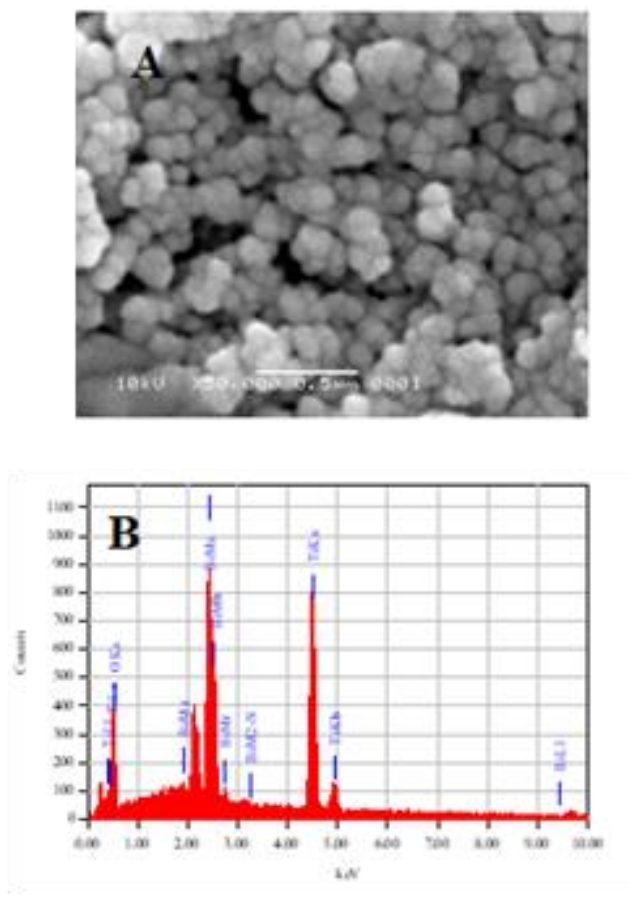

Figure 4 (A) SEM Image of Bi-TiO2-K ; (B) EDX spectrum of $\mathrm{Bi}-\mathrm{TiO} 2-\mathrm{K}$

Fig. 4 (A) provides a SEM image the prepared BiTiO2-K photocatalyst. According to the SEM image, the $\mathrm{Bi}$ atoms are homogenously dispersed on the surface of $\mathrm{TiO} 2$ nanoparticles. One may understand that the prepared photocatalyst is composed of agglomerated highdensity nanoparticles, which is expected to expand the photoresponse region, and increase the photo-carrier charge photoelectron (e-) and photohole $(\mathrm{h}+)$ transfer to the surface of the nanocomposite prior to their recombination. From the EDX spectrum Fig. 4(B), showed that the $\mathrm{Bi}-\mathrm{TiO} 2$ photocatalyst contains 3 elements, such as $\mathrm{O}, \mathrm{Ti}, \mathrm{Bi}$ and $\mathrm{Si}$, with atomic ratio are $55.38 ; 33.04 ; 4.00$ and $7.58 \%$, respectively. The bismuth content in the $\mathrm{TiO} 2$ lattice indicates that the $\mathrm{Bi} 3+$ cations have been successfully incorporated into $\mathrm{TiO} 2$ lattice. Substitution of some the Ti4+ by Bi3+ cations will reduce the photocatalyst band gap. This is consistent with the results of DRS spectra $\mathrm{Bi}-\mathrm{TiO} 2$ photocatalyst which has a band gap energy of $2.76 \mathrm{eV}$.

The effect of photocatalytic reaction of the $\mathrm{TiO} 2, \mathrm{Bi}-$ $\mathrm{TiO} 2$ and $\mathrm{Bi}-\mathrm{TiO} 2-\mathrm{K}$ photocatalyst on the growth of EC and SA under visible irradiation for 180 minutes are shown in Fig 5A and 5B respectively. Two control experiments containing only the photocatalyst under dark 
(adsorption) and light conditions (photolysis) were conducted [26]. Photolysis and adsorption phenomenon showed non-significant inactivation EC and SA. These results imply that usage visible light in the absence of photocatalyst was incapable to inactivate EC and SA bacteria [27]. It can be seen in fig 5. The $\mathrm{TiO} 2$ have a slight inactivation of EC and SA under visible light. In generally, the $\mathrm{TiO} 2$ photocatalyst cannot be activated by visible light, because its band gap (eg) is high (3.0-3.2 $\mathrm{eV})$. These results indicate that LED lamps as used as a visible light source still contain UV light at a portion of $10 \%$. It can be seen in fig. $5 \mathrm{~A}$ dan $5 \mathrm{~B}$ the $\mathrm{TiO} 2$ have a low photocatalytic bacterial inactivation.
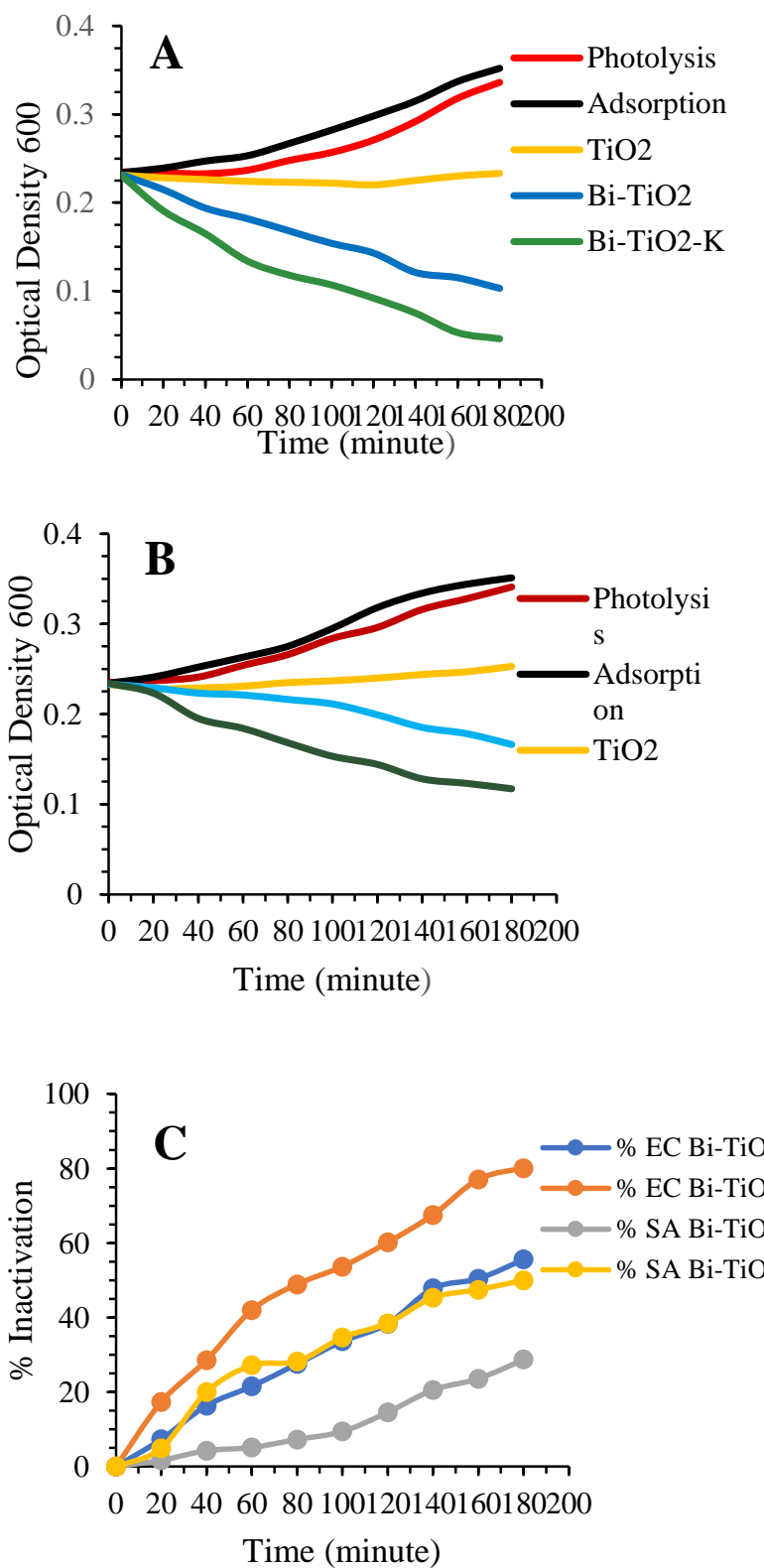

Figure 5 Growth curves: A) EC; B). SA bacteria on different processes, and (C) \% Inactivation for E. coli (EC) and S.Aureus (SA)

The Bi-TiO2 showed good inactivation for EC and SA bacteria under visible light irradiation. The optical density (OD) 600 value for EC and SA bacterial using Bi$\mathrm{TiO} 2$ is much lower than $\mathrm{TiO} 2$ after visible light irradiated for $180 \mathrm{~min}$, where arise to $0.103 ; 0.166$ and 0.253 respectively. These results are consistent with the band gap of $\mathrm{TiO} 2$ decreases from $3.22 \mathrm{eV}$ to $2.76 \mathrm{eV}$ after $\mathrm{Bi} 3+$ is incorporated into the $\mathrm{TiO} 2$ lattice site was observed in this study. It may be an indication that the formation of (e-) and $(\mathrm{h}+)$ pairs on the surface of $\mathrm{Bi}-\mathrm{TiO} 2$ photocatalyst is easier to occur than $\mathrm{TiO} 2$ when absorbing visible light as a result of the mixing of the $\mathrm{Bi}$ $2 p$ with Ti $2 p$ orbitals [27], [28]. Obviously, the Bi3+ cation doping into $\mathrm{TiO} 2$ lattice caused narrowed the band gap and improved the optical absorption visible light [11], [29].

In contrast, the photocatalytic inactivation for EC dan $\mathrm{SA}$ value showed superior of $\mathrm{Bi}-\mathrm{TiO} 2 / \mathrm{kaolinite}$ photocatalyst under visible irradiation. It can be seen in fig 5.C that photocatalytic inactivation for EC using Bi$\mathrm{TiO} 2 /$ kaolinite higher than $\mathrm{Bi}-\mathrm{TiO} 2$ photocatalyst after exposed with visible irradiation for $180 \mathrm{~min}$ capable to inactivate of EC by $80 \%$ and $55.6 \%$ respectively. For SA bacteria \% inactivation using $\mathrm{Bi}-\mathrm{TiO} 2 /$ kaolinite and $\mathrm{Bi}$ $\mathrm{TiO} 2$ photocatalyst after exposed with visible irradiation for $180 \mathrm{~min}$ was observed are $50 \%$ dan $28,75 \%$ respectively.

The immobilization of $\mathrm{Bi}$ on the kaolinite surface can expand the active site so that the adsorption capacity of bacterial substrates on the photocatalyst surface increases causing an increase in the number of inactive bacteria[19]. According to Manikandaan et al., enhancement photocatalytic inactivation bacterial under visible light in the presence of $\mathrm{Bi}-\mathrm{TiO} 2 / \mathrm{kaolinite}$ photocatalysts could be explained by the high specific surface area of kaolinite was prepared [19] to provide additional active surface sites to adsorb water molecules and to form active radical hidroxide $(\mathrm{OH} \bullet)$ [26]. There was improved the surface area of the photocatalyst caused enhance its capacity absorption. It was clearly that the higher inactivation of EC are simultaneously contribution of the high surface area of kaolinite as site active to substrate absorption. Another factor of the superoxide anion radicals $(\mathrm{O} 2-\bullet)$ and hydroxyl radicals $(\bullet \mathrm{OH})$ pairs are able to oxidize bacteria. Enhanced photocatalytic bacterial inactivation is a synergistic effect of doping $\mathrm{Bi} 3+$ on the optical properties and high surface area kaolinite on increase adsorption capacity of substrate bacteria.

The Bi-TiO2/kaolinite photocatalyst showed more higher photocatalytic inactivation of EC bacteria than SA. One of the contributing factors is may affect antibacterial properties of nanoparticles is the fact that bacterial cells produce extracellular proteins. According to the cellular wall composition the bacteria are classified as Gram-positive and Gram-negative bacteria. The E. coli is a Gram-negative bacterial with the outer cell membrane covered by a lipopolysaccharide layer of 1-3 
$\square \mathrm{m}$ thickness [32]. E. coli is a gram-negative bacteria that gives a negative charge in the solution media, it will be stronger to interact with the positively charged $\mathrm{TiO} 2$ surface, so that it is more easily adsorbed to the Bi-TiO2$\mathrm{K}$ surface compared to $\mathrm{S}$.Aureus which is positively charged. With the slightly negatively charged outer E. coli surface, it is expected that this bacterium could have an enhanced photocatalytic inactivation rate with a $\mathrm{Bi}$ TiO2-K photocatalyst. This is owing to the nature of the heterogeneous $\mathrm{TiO} 2$ photocatalytic reaction, where the bacterial contaminants transfer to the vicinity of the $\mathrm{TiO} 2$ surface for subsequent cyclic radical hidroxyl penetration

\section{CONCLUSION}

The Bi-TiO2-K photocatalyst have been fabricated. The band gap of the $\mathrm{Bi}-\mathrm{TiO} 2(2.76 \mathrm{eV})$ decrease from $3.22 \mathrm{eV}$ (anatase $\mathrm{TiO} 2$ ) was caused by incorporating $\mathrm{Bi} 3+$ cation to form $\mathrm{Bi}-\mathrm{O}-\mathrm{Ti}$ bonds caused responsive to visible light region. Immobilization of $\mathrm{Bi}-\mathrm{TiO} 2$ on the kaolinite surface increased the photocatalytic inactivating $\mathrm{EC}$ and SA bacteria after visible light irradiation for $180 \mathrm{~min}$ arise $80 \%$ and $50 \%$ inactivation $\mathrm{EC}$ and SA bacteria respectively.

\section{ACKNOWLEDGMENT}

Acknowledgments. This work was funded by the Kementerian Pendidikan, Kebudayaan, Riset \& Teknologi, Universitas Tanjungpura, Republik Indonesia.

\section{REFERENCES}

[1] H. J. Cui, H. Z. Huang, B. Yuan, and M. L. Fu, "Decolorization of RhB dye by manganese oxides: Effect of crystal type and solution $\mathrm{pH}$," Geochem. Trans., vol. 16, no. 1, pp. 10-12, 2015, doi: 10.1186/s12932-015-0024-2.

[2] G. Li et al., "Enhanced visible-light-driven photocatalytic inactivation of Escherichia coli using g-C3N4/TiO2 hybrid photocatalyst synthesized using a hydrothermal-calcination approach," Water Res., vol. 86, pp. 17-24, 2015, doi: 10.1016/j.watres.2015.05.053.

[3] S. Ma, S. Zhan, Y. Jia, and Q. Zhou, "Superior Antibacterial Activity of Fe3O4-TiO2 Nanosheets under Solar Light," ACS Appl. Mater. Interfaces, vol. 7, no. 39, pp. 21875-21883, 2015, doi: 10.1021/acsami.5b06264.

[4] D. A. Solís-Casados, L. Escobar-Alarcón, A. Arrieta-Castañeda, and E. Haro-Poniatowski, "Bismuth-titanium oxide nanopowders prepared by sol-gel method for photocatalytic applications," Mater. Chem. Phys., vol. 172, no. February, pp. 1119, Apr. 2016, doi: 10.1016/j.matchemphys.2015.12.002.
[5] P. Kehrein, M. van Loosdrecht, P. Osseweijer, M. Garfí, J. Dewulf, and J. Posada, "A critical review of resource recovery from municipal wastewater treatment plants - market supply potentials, technologies and bottlenecks," Environ. Sci. Water Res. Technol., vol. 6, no. 4, pp. 877-910, 2020, doi: 10.1039/C9EW00905A.

[6] A. B. Aritonang, E. Pratiwi, W. Warsidah, S. I. Nurdiansyah, and R. Risko, "Fe-doped TiO2/Kaolinite as an Antibacterial Photocatalyst under Visible Light Irradiation," Bull. Chem. React. Eng. Catal., vol. 16, no. 2, pp. 293-301, 2021, doi: 10.9767/bcrec.16.2.10325.293-301.

[7] A. B. Aritonang, Y. K. Krisnandi, and J. Gunlazuardi, "Modification of $\mathrm{TiO} 2$ nanotube arrays with $\mathrm{N}$ doping and $\mathrm{Ag}$ decorating for enhanced visible light photoelectrocatalytic degradation of methylene blue," Int. J. Adv. Sci. Eng. Inf. Technol., vol. 8, no. 1, pp. 234-241, 2018, doi: 10.18517/ijaseit.8.1.2342.

[8] V. Caratto et al., "Atividade antibacteriana de tubos endotraqueais revestidos com dióxido de titânio padrão e dopados com nitrogênio: Um estudo in vitro,” Rev. Bras. Ter. Intensiva, vol. 29, no. 1, pp. 55-62, 2017, doi: 10.5935/0103-507X.20170009.

[9] P. A. K. Reddy, B. Srinivas, P. Kala, V. D. Kumari, and M. Subrahmanyam, "Preparation and characterization of $\mathrm{Bi}$-doped $\mathrm{TiO} 2$ and its solar photocatalytic activity for the degradation of isoproturon herbicide," Mater. Res. Bull., vol. 46, no. 11, pp. 1766-1771, Nov. 2011, doi: 10.1016/j.materresbull.2011.08.006.

[10] S. Murcia-López, M. C. Hidalgo, and J. A. Navío, "Synthesis, characterization and photocatalytic activity of Bi-doped $\mathrm{TiO} 2$ photocatalysts under simulated solar irradiation," Appl. Catal. A Gen., vol. 404, no. 1-2, pp. 59-67, 2011, doi: 10.1016/j.apcata.2011.07.008.

[11] H. Mao, Z. Jin, F. Zhang, H. He, J. Chen, and Y. Qian, "A high efficiency photocatalyst based on porous Bi-doped $\mathrm{TiO} 2$ composites," Ceram. Int., vol. 44, no. 14, pp. 17535-17538, 2018, doi: 10.1016/j.ceramint.2018.06.074.

[12] P. Magesan and A. Sviaranijani, "Synthesis and Characterization of Bismuth Oxide Doped Titanium Dioxide and Its Antibacterial Activity," Int. J. Pure Appl. Math., vol. 119, no. 12, pp. 6345-6359, 2018, [Online]. Available: http://www.ijpam.eu.

[13] H. Li, J. Liu, J. Qian, Q. Li, and J. Yang, "Preparation of Bi-doped $\mathrm{TiO} 2$ nanoparticles and their visible light photocatalytic performance," Cuihua Xuebao/Chinese J. Catal., vol. 35, no. 9, pp. 
1578-1589, 2014, doi: $10.1016 / \mathrm{S} 1872-$ 2067(14)60124-8.

[14] N. V. S. Praneeth and S. Paria, "Clay-supported anisotropic Au-modified N,S-doped TiO2 nanoparticles for enhanced photocatalytic dye degradation and esterification reactions," New J. Chem., vol. 44, no. 6, pp. 2619-2629, 2020, doi: 10.1039/c9nj05306a.

[15] J. Ma, J. Chu, L. Qiang, and J. Xue, "Synthesis and structural characterization of novel visible photocatalyst $\mathrm{Bi}-\mathrm{TiO} 2 / \mathrm{SBA}-15$ and its photocatalytic performance," RSC Adv., vol. 2, no. 9, p. 3753, 2012, doi: 10.1039/c2ra01199a.

[16] W. Zhou, P. Zhang, and W. Liu, "Anatase TiO 2 nanospindle/activated carbon (AC) composite photocatalysts with enhanced activity in removal of organic contaminant," Int. J. Photoenergy, vol. 2012, pp. 28-30, 2012, doi: 10.1155/2012/325902.

[17] V. L. Chandraboss, J. Kamalakkannan, and S. Senthilvelan, "Synthesis of activated charcoal supported Bi-doped $\mathrm{TiO} 2$ nanocomposite under solar light irradiation for enhanced photocatalytic activity,” Appl. Surf. Sci., vol. 387, pp. 944-956, 2016, doi: 10.1016/j.apsusc.2016.06.110.

[18] T. H. da Silva et al., "Kaolinite/TiO2/cobalt(II) tetracarboxymetallophthalocyanine

nanocomposites as heterogeneous photocatalysts for decomposition of organic pollutants trimethoprim, caffeine and prometryn," J. Braz. Chem. Soc., vol. 30, no. 12, pp. 2610-2623, 2019, doi: 10.21577/0103-5053.20190178.

[19] K. Dědková et al., "Antibacterial activity of kaolinite/nanoTiO2 composites in relation to irradiation time," J. Photochem. Photobiol. B Biol., vol. 135, pp. 17-22, 2014, doi: 10.1016/j.jphotobiol.2014.04.004.

[20] B. E. Nagay et al., "Visible-Light-Induced Photocatalytic and Antibacterial Activity of $\mathrm{TiO} 2$ Codoped with Nitrogen and Bismuth: New Perspectives to Control Implant-Biofilm-Related Diseases," ACS Appl. Mater. Interfaces, vol. 11, no. 20, pp. 18186-18202, 2019, doi: 10.1021/acsami.9b03311.

[21] J. Xin, S. Zhang, and G. Qi, "PREPARATION AND CHARACTERIZATION OF THE Bi-DOPED TiO 2 PHOTOCATALYSTS Jian-Hua Xin, Shou-Min Zhang *, Guang-Dong Qi, Xiu-Cheng Zheng, WeiPing Huang and Shi-Hua Wu," vol. 86, no. 2, pp. 291-298, 2005.

[22] Y. Astuti, B. M. Listyani, L. Suyati, and A. Darmawan, "Bismuth oxide prepared by sol-gel method: Variation of physicochemical characteristics and photocatalytic activity due to difference in calcination temperature," Indones. J. Chem., vol. 21, no. 1, pp. 108-117, 2021, doi: 10.22146/ijc.53144.

[23] A. El Mragui, Y. Logvina, L. Pinto da Silva, O. Zegaoui, and J. C. G. Esteves da Silva, "Synthesis of $\mathrm{Fe}$ - and $\mathrm{Co}-$ Doped $\mathrm{TiO} 2$ with Improved Photocatalytic Activity Under Visible Irradiation Toward Carbamazepine Degradation," Materials (Basel)., vol. 12, no. 23, p. 3874, Nov. 2019, doi: 10.3390/ma12233874.

[24] M. A. M. Khan, S. Kumar, A. N. Alhazaa, and M. A. Al-Gawati, "Modifications in structural, morphological, optical and photocatalytic properties of $\mathrm{ZnO}: \mathrm{Mn}$ nanoparticles by sol-gel protocol," Mater. Sci. Semicond. Process., vol. 87, pp. 134141, Nov. 2018, doi: 10.1016/j.mssp.2018.07.016.

[25] M. Salimi et al., "A new nano-photocatalyst based on $\mathrm{Pt}$ and $\mathrm{Bi}$ co-doped $\mathrm{TiO} 2$ for efficient visiblelight photo degradation of amoxicillin," New J. Chem., vol. 43, no. 3, pp. 1562-1568, 2019, doi: 10.1039/c8nj05020a.

[26] V. Manikandan, M. A. Mahadik, I. S. Hwang, W. S. Chae, J. Ryu, and J. S. Jang, "Visible-Light-Active CuOx-Loaded Mo-BiVO4Photocatalyst for Inactivation of Harmful Bacteria (Escherichia coliandStaphylococcus aureus) and Degradation of Orange II Dye," ACS Omega, vol. 6, no. 37, pp. 23901-23912, 2021, doi: 10.1021/acsomega.1c02879.

[27] N. Khadgi, A. R. Upreti, and Y. Li, "Simultaneous bacterial inactivation and degradation of an emerging pollutant under visible light by $\mathrm{ZnFe} 2 \mathrm{O} 4$ co-modified with Ag and rGO," RSC Adv., vol. 7, no. 43, pp. 27007-27016, 2017, doi: $10.1039 / \mathrm{c} 7 \mathrm{ra} 01782 \mathrm{k}$.

[28] D. A. Solís-Casados, L. Escobar-Alarcón, A. Arrieta-Castañeda, and E. Haro-Poniatowski, "Bismuth-titanium oxide nanopowders prepared by sol-gel method for photocatalytic applications," Mater. Chem. Phys., vol. 172, no. February, pp. 1119, 2016, doi: 10.1016/j.matchemphys.2015.12.002.

[29] B. Benalioua, M. Mansour, A. Bentouami, B. Boury, and E. H. Elandaloussi, "The layered double hydroxide route to $\mathrm{Bi}-\mathrm{Zn}$ co-doped $\mathrm{TiO} 2$ with high photocatalytic activity under visible light," J. Hazard. Mater., vol. 288, pp. 158-167, 2015, doi: 0.1016/j.jhazmat.2015.02.013. 